Case Report

\title{
Winnowing fan blade head injury: a farm mishap
}

\author{
Sedain G, Basnet R, Sharma M,Silpakar S \\ Neurosurgery unit, Department of Surgery, Tribhuvan University Teaching Hospital
}

Correspondence: Gopal Sedain, Assistant Professor, Neurosurgery unit, Department of Surgery, Tribhuvan University Teaching Hospital

Email: newron79@gmail.com

\begin{tabular}{l} 
Abstract \\
\hline \hline In an agriculture based economy like Nepal farm related accidents are not uncommon. Indigenous \\
farm machinery like winnowing fan is common in our villages. Five cases of fan related head injuries \\
presenting to the Department of Surgery, Tribhuvan University Teaching Hospital in a single month \\
of winnowing season are discussed. \\
Key words: fan blade, head injury, winnowing \\
\hline \hline
\end{tabular}

\section{Introduction}

Nepal is an agriculture based economy and farming methods are still primitive. Winnowing machines made by local blacksmith are being used commonly these days. These machines are used to separate grain from chaff during harvesting season by wind current created due to running fan.(Figure 1) As farmers have to spend much of their time around these indigenous machines, they are at risk of being injured by them.

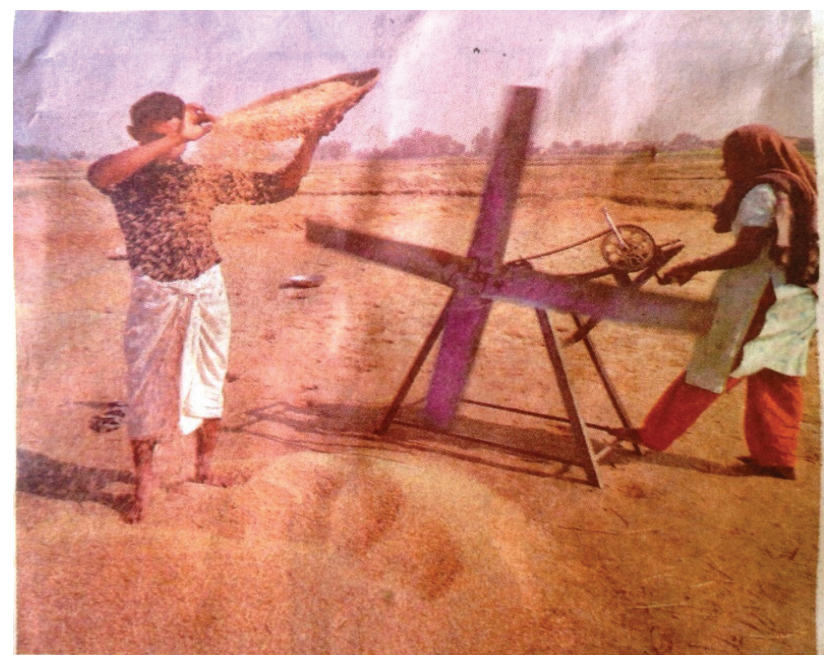

Figure 1: Winnowing machines commonly used in villages
No data regarding winnowing fan blade injury is available in our country and limited information is available even in literature. A study in India have reported 31 cases over a period of 5 years. $^{2}$ Analysis of 5 cases of head injury by winnowing fan blade presenting to our centre has been discussed.

\section{Methods}

We conducted analysis of 5 cases of head injury sustained by winnowing fan blade between November 2012-December 2012 to the Department of Surgery, Tribhuvan University Teaching Hospital, Kathmandu, Nepal. The patients' clinical status, CT findings and operative notes were studied.

\section{Results}

Out of five patients, 3 were children and 2 were adults. 3 victims were females and 2 were male. Three were injured by falling onto a spinning fan, and one was injured by blade of fan as the blade gave away. Another patient got injured as the chain of machine caught her hair. Most have left sided head injuries involving frontal region. All patients had scalp laceration with wound length ranging from $5 \mathrm{cms}$ to avulsion of the scalp. (Table 1) 
Table 1: Types of injury

\begin{tabular}{|c|c|c|}
\hline Injury & Number & Management \\
\hline $\begin{array}{l}\text { Compound linear } \\
\text { fracture }\end{array}$ & 2 & $\begin{array}{l}\text { Debridement } \\
\text { and wound } \\
\text { repair }\end{array}$ \\
\hline $\begin{array}{l}\text { Compound depressed } \\
\text { fracture with } \\
\text { pneumocephalus }\end{array}$ & 1 & $\begin{array}{l}\text { Craniotomy } \\
\text { with elevation } \\
\text { of bone flap }\end{array}$ \\
\hline $\begin{array}{l}\text { Compound depressed } \\
\text { fracture with contusion } \\
\text { with pneumocephalus }\end{array}$ & 1 & Conservative \\
\hline $\begin{array}{l}\text { Frontal Contusion with } \\
\text { degloving injury of scalp }\end{array}$ & 1 & $\begin{array}{l}\text { Split Skin } \\
\text { Grafting }\end{array}$ \\
\hline
\end{tabular}

A 9 year female child sustained injury due to the blade and had linear fracture of frontal bone and injury to the globe. (Figure 2) Two patients underwent debridement and repair under general anesthesia. One patient underwent wound toileting and suturing under local anesthesia. (Figure 3) One patient required craniotomy and elevation of depressed fracture under general anaesthesia. (Figure 4) One patient with avulsion of scalp needed debridement and split Skin Grafting (Figure 4, Figure 5).

Mean hospital stay of 5 days (range 2-14). The duration of follow up ranged from 2-12 weeks, with a mean of 4 weeks.

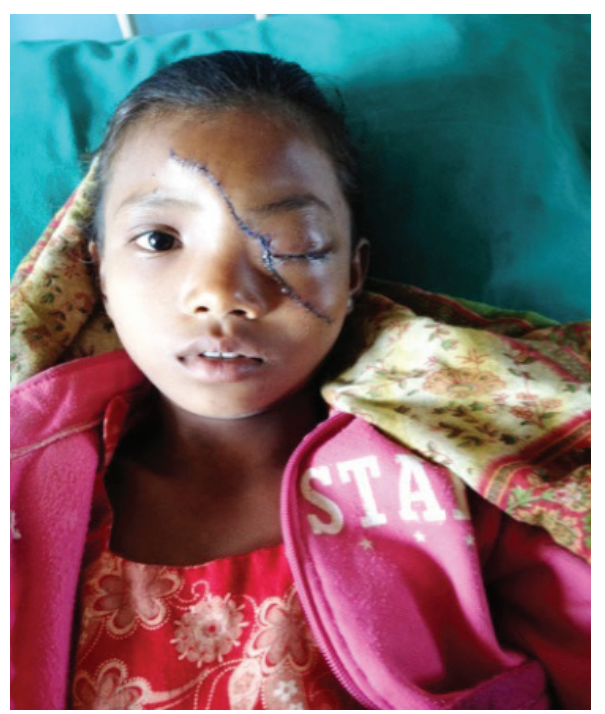

Figure 2: Injury due to the blade with linear fracture of frontal bone and injury to the globe.

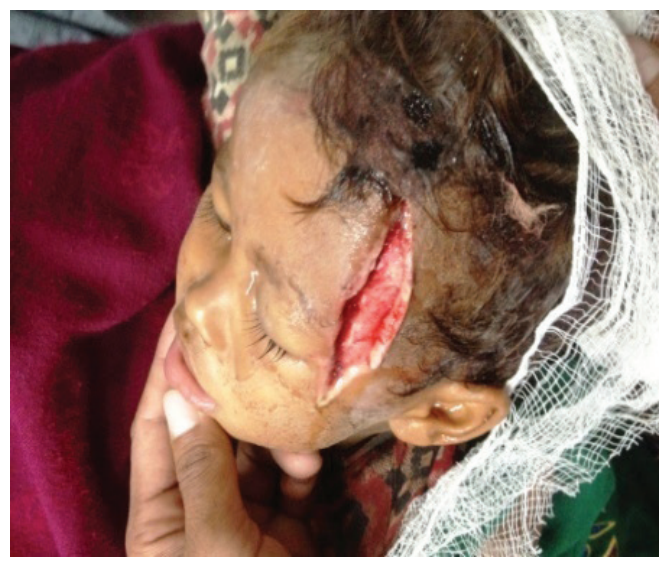

Figure 3: Two year child with laceration and depressed fracture.
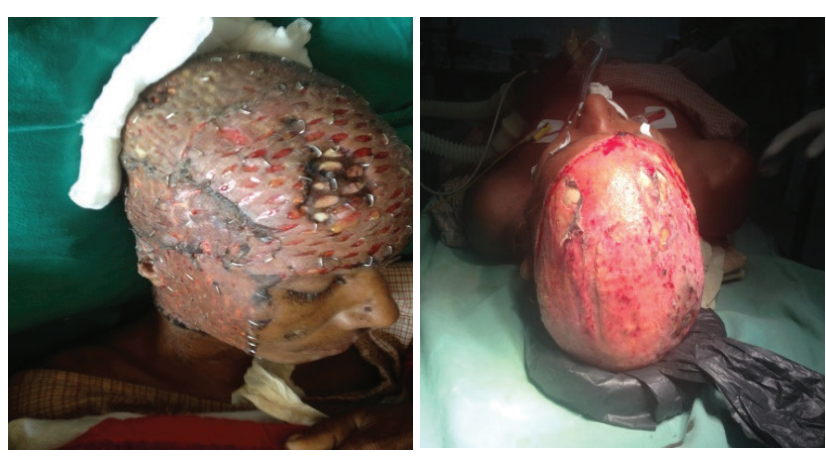

Fig 4 and 5: Avulsion of scalp with intact pericranium.

\section{Discussion}

Work place injuries due to machines are common. Farms are also unsafe when agricultural machinery can lead to serious injuries. Adults can take precautions to keep themselves safe. However, children of farmers often accompany them to the field and due to curiosity tend to play near these potentially dangerous machines. Children were the most common victims in the large series of 31 patients reported during a period of 5 years from Institute of medicine, Varanasi, India ${ }^{1}$. A pediatric case of winnowing blade injury was reported in 2008 from Lucknow in India. ${ }^{2}$ Head injury is the most common type of farm or agriculture-related injury in preschool children. ${ }^{3}$ In a pediatric neurosurgical unit of a hospital from Kualalumpur 14 cases of fan blade injuries were reported. ${ }^{4}$ 
Playing nearby working area is dangerous as children get hit by spinning fan and adults can also sustain injury by giveaway of fan of blade. Women especially with long hair get their hair caught by chain resulting in degloving injury along with head injury.

A winnowing fan blade is blunt object but tends to become sharp object as the fan rotates resulting in penetrating head injury. The severity depends on speed of rotating fan.

The causes of winnowing fan-blade head injury in this series were preventable. As a preventive measure, winnowing fan blade should be covered by iron bars. The children should be kept away from farm. Appropriate safe playground should be created so that they won't accompany their parents in farm. Mothers and parents should be educated about hazard of fan blade and safety measures to prevent it. Women should keep their long hair rolled while going to farm.

\section{Conclusion}

Injuries due to winnowing fan blade are potential hazard that can be prevented. Head Injury often results due to lack of awareness about safety measures and carelessness. By increasing safety awareness, the majority of injuries can be prevented.

\section{Acknowledgements:}

Department of Plastic Surgery, Institute of Medicine, TUTH for skin grafting.

\section{References}

Kumar A., Shankar R., Pandey R., et al. Five years' experience at a single centre of craniocerebral injury from winnowing fan blades. J Clin Neurosc2010; 17:178-181

Kaif M, Singh G,Husain M, et al. Winnowing fan blade head injury. Indian Journal of Neurotrauma 2008; 5(1) 4950

Miers S, Baerg J. Farm accidents in children: eleven years of experience. J Paed Surg 2001; 36:726-9

Alias A, Krishnapillai R, Teng HW et al. Head injury from fan blades among children. Asian J Surg. 2005 Jul; 28(3):168-70 